\title{
Housing Wealth and Residential Energy Consumption
}

\begin{abstract}
The housing wealth effect manifests as a positive relationship between consumption and perceived housing wealth. When the perceived value of a property rises, homeowners may feel more comfortable and secure about their wealth, causing them to spend more. This study adopts a behavioural approach to verify if this relationship holds true for residential energy consumption. An analytical framework is proposed to study the relationship between housing wealth and energy consumption at both the market and the individual level. We find evidence of significant association between housing wealth and energy consumption by using data between 1995 and 2016 from the UK. As the perception of housing value increases, UK residents tend to increase their energy consumption. Our models also consider psychological biases in energy consumption behaviours, such as market sentiment in the macro-level analysis and framing effect in the micro-level investigation. Our findings shed light on the behavioural aspects of housing wealth effect on residential energy consumption and demonstrate the potential of using behavioural interventions to encourage energy conservation activities. These findings are helpful in designing and implementing energy consumption policies that can strike a balance between social justice and economic efficiency.
\end{abstract}

Keywords: Prospect theory, mental accounting, behavioural economics, energy consumption, housing wealth, judgemental bias

JEL Classification: Q40, Q50, R20 


\section{Housing Wealth and Residential Energy Consumption}

\section{Introduction}

Residential energy consumption represents more than a quarter of the total energy consumption in most countries and plays a significant role in mitigating global climate change. Therefore, considerable efforts have been made to examine energy consumption in households. Unlike transport or industrial energy consumption, which is mostly affected by technological standards and regulations, residential energy consumption is determined by a wide range of factors. The physical characteristics of residential buildings, such as construction materials, property structure and efficiency level of appliances, are important determinants of energy consumption (Druckman and Jackson, 2008; Valenzuela et al., 2014). Studies also show that energy consumption can be largely influenced by household features (Tso and Guan, 2014; Valenzuela et al., 2014). Household characteristics can determine energy consumption via the direct channel of their adoption of energy saving technology and the indirect channel of their choices of housing units (Estiri, 2014). For example, small energy saving measures (e.g., smart metres and in-home displays) have seen significant technological development recently (see, for instance, Sanchez-Sutil et al., 2019; Valor et al., 2019). Households that are more environmentally conscious or with higher incomes are more likely to adopt these new devices to save energy (Druckman and Jackson, 2008; Gatersleben et al., 2002; Jackson et al., 2007; Wood et al., 2019). Families with children tend to live in larger homes. As a result, household size has a positive impact on the total energy consumption (Ndiaye and Gabriel, 2011) and a negative impact on per capita energy consumption (Brounen et al., 2012).

Although building and household characteristics are crucial in determining the basic requirements of energy consumption, they are not well suited to capture the effects of energy consumption behaviours or habits. Furthermore, the role of these human factors has received growing interests. When households receive feedback on their energy consumption levels, their electricity consumption is reduced by $20 \%$, with older and energy-conservative groups likely to be affected by such feedback (Aydin et al., 2018). The real-time display of energy use can lead to energy-conservative behaviour in households through the learning channel (Lynham et al., 2016). Accordingly, a sociopsychological perspective about residential energy consumption has been emerging (Nye et al. (2010).

We extend this line of research by studying the relationship between housing wealth and energy consumption. Housing wealth, defined as the total market value of the housing capital, is an important component of the total wealth of households. Housing wealth is different from financial wealth in many ways. Housing wealth is more important for households with their wealth within the median range. However, financial wealth has an unequal distribution and matters for those in the top quantile. Financial wealth is more sensitive to short-term shocks, whereas housing wealth is more responsive to long-term shocks. Although households can track financial wealth from the stock market on a daily basis, they do not receive frequent market feedback

on their housing wealth. Moreover, housing wealth is less liquid than financial wealth from the stock market. Financial wealth can be easily liquidated and used to fulfil 
purchases. By contrast, housing wealth does not give households an instant benefit to consume. Therefore, it mainly influences consumption by increasing borrowing power or, in most cases, making homeowners feel wealthier psychologically. This psychological effect is not negligible. Housing wealth effect on general consumption has been increasing over the past 30 years (Kishor, 2007), and general consumption is much more responsive to changes in housing wealth than that in financial wealth (see Aladangady (2017); Carroll et al. (2011). Significant housing wealth effect on consumption in many countries has been well documented (Bostic et al., 2009; Kishor, 2007; Paiella, 2007; Sonje et al., 2012).

Given the significant influence that housing wealth asserts on general consumption, the present study investigates whether changes in housing wealth will affect energy consumption levels. An increase in housing wealth effect does not necessarily mean that the owner will gain more cash, particularly when the homeowner cannot sell her only house. However, it can increase life satisfaction (Chen, 2006), improve expectation (Ludwig and Sløk, 2002), reduce precautionary savings (Campbell and Cocco, 2007; Carroll, 1992) or even improve one's financial situation through refinancing (Attanasio et al., 2009; Gan, 2010). These changes can potentially affect the household energy consumption level. Given the size and growing volatility of housing markets across the world, the role of housing wealth in energy consumption determination deserves scientific investigation.

Studies link household wealth to energy consumption. Household energy consumption increases with household wealth (Huang, 2015; Rao and Reddy, 2007). Household wealth can also affect households' choice of energy sources (Khandker et al., 2012; Rahut et al., 2017). An increase in household wealth can lead to an increased propensity to pay for a better quality of energy source, which is shown by the acceleration of electrical use for light and cooking in such households (Rahut et al., 2017). Households tend to use modern, efficient stoves and high-quality fuels when their wealth level increases (Takama et al., 2012). The energy price shock, such as that of crude oil, can affect the macro economy through the wealth-consumption channel (Odusami, 2010). The price fluctuation of crude oil affects the household consumption to wealth response partly because more than half of the energy spending is related to crude oil.

Following the analytical frameworks identified by Swan and Ugursal (2009), we investigate housing wealth effect on domestic energy consumption at the macro and micro levels. We collect data from the UK to test our hypotheses. Vector Error Correction Models are estimated with time series data from 1995Q4 to 2016Q4 in the macro-level analysis. A large household panel survey dataset from the Understanding Society Study is used in the micro-level analysis. Overall, we find a significant positive relationship between housing wealth and energy consumption. Age, financial situation and energy-conservative attitude all serve as moderators in the housing wealth effect on energy consumption. From the behavioural perspective, we identify a framing effect, with combined payment method linked to a stronger housing wealth effect on energy consumption. Finally, housing wealth effect shows varying patterns in the upper and lower halves of the energy consumption distribution, reflecting significant housing wealth effects among households with high fuel poverty level. 
This study contributes to the literature in two ways. From the methodological perspective, we combine macro- and micro-level analysis of housing wealth effect on residential energy consumption in one unified analytical framework. We also consider behavioural biases, e.g., framing effect, in our models. By investing household behaviours both individually and collectively, and by recognising the role of both rational and irrational energy consumption decision making, our analytical framework facilitates reliable identification of housing wealth effect in the residential energy sector. On the empirical front, we provide some much-needed field evidence on both energy conservation studies and behavioural research. Existing behavioural studies of energy saving in the UK are limited in both depth and scope. For example, Revell (2014)'s survey on household energy visit programme include only 118 households in London, Wood and Newborough (2003) conducted field experiment with 44 households in their study of energy consumption indicators, and Chiang et al. (2014) considered student residents only when investigating how in-home displays change energy consumption behaviours. Our empirical analysis adopts data from the Understanding Society Study, which is the largest longitudinal household panel study in the world. This is a significant improvement over existing studies in terms of external validity.

The remainder of the paper is structured as follows. Section 2 discusses the analyses on the long-run relationship between housing wealth and residential energy consumption by using macro data. Section 3 presents the micro-level analysis using household survey data. Section 4 concludes the paper.

\section{Background}

Since the 1950s, the liberalization of financial market greatly facilitated the development of mortgage markets. Homebuyers enjoyed eased credit constraints and a wide range of products and services. As a result, residential property markets play an increasingly important role in investment and consumption decisions. The proportion of housing wealth, measured as a percentage of both national GDP and household total wealth, has been increasing steadily in the last 50 years. It is now stabilized at around $4 \%$ of the GDP of the UK. In Table 1, the size of housing and financial wealth among British households are given as a percentage of GDP between 1936 and 2016. Although the speed of housing wealth expansion was slowed down by the Global Financial Crisis, the trajectory was not changed. The gap between housing wealth and financial wealth continues to widen. Table 1 also gives the absolute values of housing wealth and financial wealth between 2006 and 2018. Although the provisional statistics for 2016 and 2018 shows a sign of financial wealth catching up, the housing wealth still dwarfs financial wealth in both absolute and relative measurements among UK households. It is, therefore, important to understand how changes in housing wealth affect UK households' consumption decisions.

\section{[ Insert Table 1 here]}

Figure 1 gives three time series of domestic energy expenditure in the UK. Energy expenses are presented as the percentage of total household expenditure for all households, households in the lowest $10 \%$ of incomes, and household in the highest $10 \%$ incomes. Energy expenditure accounts for four to five percent of total household expenditure on average in the UK. However, the lowest incomes group spent a disproportionally higher share of their income on energy, as indicated by the large gap 
between the solid line (i.e., lowest $10 \%$ incomes group) and the dash line (i.e., the national average). Basic energy costs sometimes took up more than $10 \%$ of total expenditure among these poor households. Figure 1 highlights the importance of analysing energy consumption by income groups, as households in different income groups face different budget constraints. Consequently, they are likely to have different energy consumption behaviours.

We also include housing wealth in Figure 1 to demonstrate the connection between energy consumption and housing wealth. We use relative measurements for these time series to facilitate comparison. In general, there seems to be a negative relationship between energy expenditure and housing wealth, with energy consumption lagging behind housing wealth by at least one year. As housing wealth increases, energy expenses as a proportion of total household expenditure decreases accordingly, and vice versa. This pattern supports the conventional wisdom that energy consumption level is relatively fixed. Given domestic energy costs do not fluctuate significantly over time, the level of energy expenses remains stable through economic cycles. However, the share of energy expenditure in total household expenditure will move, in opposite direction, with income level and housing wealth.

A close examination of Figure 1 reveals a more complex picture. The energy expenditure for the bottom $10 \%$ income group fluctuates much more than that of the average and the top $10 \%$ income groups. Again, this pattern indicates that households in different income groups have different energy consumption behaviours. While on average energy consumption level remains stable across all households, the bottom $10 \%$ income group over-adjusts their energy expenditure corresponding to housing wealth changes. We will further explore this pattern in the micro-level empirical analysis section.

\section{[ Insert Figure 1 here]}

Finally, some latest social and economic statistics are given in Table 2 for selected OECD countries, including the UK. The statistics covers important factors that may affect energy consumption, such as age, education, homeownership rate, GDP per capita, unemployment rate, and energy price index. In all areas considered, the UK is at the average level among selected countries. It is also true when all OECD countries are considered. Therefore, the UK is a representative case, and the findings in this paper can be generated to other OECD countries and other similar settings.

\section{[ Insert Table 2 here]}

\section{Long-run relationship between housing wealth and energy consumption}

We first examined the long-run relationship between housing wealth and energy consumption at the national level. A total of three energy consumption variables were considered, namely, total energy consumption, gas consumption and electricity consumption. For comparison purposes, we also considered three general consumption measurements: total consumption, goods consumption and services consumptions. For each of the six types of consumption, we used the following equation to capture the impacts from housing wealth. 
$\frac{C}{Y}=f\left(\frac{H W}{Y}, \frac{F W}{Y}, S\right)+\varepsilon$,

where $C$ is the consumption, $H W$ is the housing wealth, $F W$ is the financial wealth, $Y$ is the household disposable income and $S$ is the market sentiment. Consumption and wealth variables are income adjusted to remove the size effect of the income (Deaton, 1992; Paiella, 2007). By expressing consumption and wealth as ratios of household disposable income, Equation (1) can reliably separate the net effect of housing wealth. Market sentiment is considered in Equation (1) due to its well-established relationship with consumption (Ludvigson, 2004).

We obtained data on consumption and wealth from the Office for National Statistics UK. We use GfK's consumer confidence index ${ }^{1}$ to measure market sentiment. Variable definitions and descriptive statistics are presented in Table 3. All variables are quarterly time series from 1995Q4 to 2016Q4. In Figure 2, we contrast the consumption and wealth variables before and after the income adjustment. The relationship between consumption and market sentiment is apparent after the income adjustment. This pattern shows the benefits of the income-adjustment strategy as shown in Equation (1).

Augmented Dickey-Fuller unit root tests confirm that all variables are integrated of order one or I(1). According to the Johansen trace test, only one cointegration relationship exists between consumption and other variables. We proceeded to estimate Equation (1) by using the vector error correction model (VECM), which is routinely used to estimate long-term relationships in the energy economics literature (See, for example, Iyke, 2015; Miller and Ratti, 2009; Shahbaz et al., 2017). AIC and BIC statistics suggest that no lagged terms should be included in the VECM models ${ }^{2}$. The coefficient estimates and model fitting statistics are reported in Table 4.

Housing wealth has a long-run positive effect, albeit statistically insignificant, on total consumption and goods consumption. For example, the estimated housing wealth effect on total consumption is 2.1840 . This case means that when housing wealth to income ratio increases by $1 \%$, the total consumption to income ratio goes up by $0.002184 \%{ }^{3}$. However, the relationship is insignificant at any conventional level. Housing wealth primarily affects the consumption of services, which is indicated by the only statistically significant housing wealth effects in model 3 . The results of the first three models generally support the life-cycle model prediction (Ando and Modigliani (1963); Gourinchas and Parker (2002)): after adjusting for the income level, changes in housing and financial wealth do not affect consumption level in the long term.

\footnotetext{
${ }^{1} \mathrm{GfK}$ 's consumer confidence index is the longest running and one of the most watched indicators in the UK. On behalf of the European Commission, GfK conducts the UK consumer confidence survey on a representative sample, focusing on their opinions on household finances, purchasing climate and the general economy.

${ }^{2}$ VECM allows the identification of reverse causality from energy consumption to housing wealth. However, there is no existing literature to support such relationship, and our empirical findings do not produce any significant results either. Therefore, we report only the coefficient estimates for models using housing wealth as the independent variables in Table 4.

${ }^{3}$ Housing wealth and financial wealth are measured in £billions, whereas consumptions are in £millions. Therefore, we accordingly made adjustments to the coefficient estimates.
} 
We then investigated the effects of financial and housing wealth changes on energy consumption. Energy consumption is classified as goods consumption by the Office for National Statistics and is included in the goods consumption statistics. Although goods consumption as a whole does not respond to wealth changes in the long run, a positive housing wealth effect is identified for all three energy consumption models (i.e. models 4-6 in Table 4). After controlling for income effects and market sentiment, energy consumption (i.e. total, gas and electricity) as a ratio of income will increase in the long term when housing wealth-income ratio increases. The effect is smaller in magnitude than that of general consumption (i.e. total, goods and services consumption) but with high statistical significance. The coefficient estimates of housing wealth variables are $1.0295,0,8829$ and 0.3002 in the total energy, gas and electricity consumption models, respectively, all of which are less than one-third of that in the services consumption model (i.e. Model 3 in Table 4). This lasting effect of housing wealth on energy consumption is at odds with the life-cycle model prediction. It does not, however, suggest a failure of a long-established classic model but suggests that some sector-specific characteristics should be considered to make sense of the anomaly. This conclusion leads to our decision to examine the housing wealth effects on energy consumption by using household- and individual-level data. Such an approach allows the consideration of household and individual traits, which proved to be influential on energy consumption behaviours (e.g. Aydin et al., 2018; Sapci and Considine, 2014; Willis et al., 2011).

Two other interesting findings in this analysis were used in the design of our household-level analysis. Firstly, in all six models, financial wealth does not have any long-term relationship with consumption, nor does it respond to deviations from the long-term equilibrium. This finding is true with or without the consumer confidence measurement in the models, which rules out the concerns over the high correlation between the two variables. Our empirical evidence suggests that financial wealth effects are insignificant in the long run. One might be tempted to omit financial wealth in the household-level analysis. This case is particularly true when the reliable measurement of financial wealth on household level can hardly be obtained, which is true for the UK. However, the insignificant financial wealth effect may be misleading due to the limitations of macro data. In response to the concern associated with estimating wealth effects with macro data (Dolmas, 2003), we further investigated the robustness of the findings by using alternative measurements and reliable proxies of financial wealth in our micro-level analysis.

Secondly, the consistently positive effect of market sentiment also shows the importance of considering behavioural factors (e.g. market sentiment) in housing wealth effect studies. This finding leads us to take into account behavioural biases in our micro-level analysis as well. Non-price behavioural interventions can encourage environment conservation activities in the residential sector. For example, smart metre and in-house display units are designed to help household to overcome self-control problems and save energy spending (Chiang et al., 2014; Revell, 2014). A carefully crafted notecard can nudge households to take up residential energy audit, an effective way to identify energy inefficiency and save energy costs (Gillingham and Tsvetanov, 2018). Lundgren and Schultzberg (2019) suggest that a simple change of payment time period can stimulate the monitoring of bills and consequently change incentives for energy conservation. However, none of these studies link housing wealth with energy expenditure. We bridge this gap in the literature with our micro-level analysis. 


\section{[ Insert Figure 2 here ] \\ [ Insert Table 3 here ] \\ [ Insert Table 4 here ]}

\section{Micro-level analysis using household survey data}

\section{1: Data Sources}

We obtained the data from the Understanding Society Study (USS) ${ }^{4}$. USS, previously called the UK Household Longitudinal Study, is the largest household study in the world. It surveys approximately 40,000 British households online on an annual basis since 2009. The study covers a wide range of social, economic and behavioural factors on the household and individual levels. Moreover, the participants of the study come from all ages and across all regions of the UK. The USS database has been widely used by researchers in the UK and overseas (see Booth et al., 2002; Clark et al., 2003; Thomas et al., 2005).

Our dataset was composed by drawing information from several waves of the Innovation Panel (IP) within the USS. A total of 2,760 households were selected from the USS main survey database to participate in the IP study, which serves as a testbed for new ways of collecting data or conducting new research. The IP questionnaire consists of two sets of questions. The first set of questions is almost identical to those asked in the main survey. Therefore, this set of questions largely remains unchanged over time. The second set of questions, however, contains experiments and methodological tests designed to develop and evaluate methodologies and new content for longitudinal survey research. Consequently, this set of questions typically changes every year. The USS holds an annual IP competition to invite ideas from the public. Winners of the competition will have their questions included in the second half of the IP questionnaire and have their ideas reliably tested with the data collected. The public also benefits from the IP study by gaining free data on cutting-edge research topics. For example, in wave 9 (i.e. survey conducted in 2016 and results released in 2017), the IP included experiments on opinions towards immigration, education expectations and 'successful aging'. It also included experiments to explore potential venues to improve survey designs, such as the impact of incentives on response rates, efficiency of fieldwork and costs. To leverage the versatile survey design of the IP study, we collected data from five IP waves between 2011 and 2015, as shown in Table 3.

\section{2: Models and Variables}

\subsubsection{Life-cycle model}

Our first step is to test the basic relationship between housing wealth and energy consumption. After adjusting the effect of household income, the relationship between

\footnotetext{
${ }^{4}$ Website: $\underline{\text { www.understandingsociety.ac.uk }}$
} 
housing wealth and energy consumption can be captured by the life-cycle model as in Ando and Modigliani (1963).

$\frac{C_{i t}}{Y_{i t}}=\beta_{0}+\beta_{1} \frac{W_{i t}}{Y_{i t}}+\varepsilon_{i t}$,

where $W_{i t}$ is the housing wealth of household $i$ in period $t, Y_{i t}$ is the household income and $C_{i t}$ is the energy consumption. $t$ refers to the time period from 2011 to 2015 . We used the reported values of the question '[what is] the expected property value if the property is sold today?' as the measurement of $W_{i t} . Y_{i t}$ is calculated based on the reported gross income for the month before the interview date. $C_{i t}$ is derived based on three variables from the IP survey: xpelecy (how much money is spent on electricity), xpgascy (how much money is spent on gas) and xpduely (how much money is spent on gas and electricity combined). When a household pays energy expenses in a combined bill, we used the reported value of xpduely as the measurement of annual household energy consumption. For households that separately pay their energy bills, we add the values of reported electricity bill payment (i.e. xpelecy) and gas bill payment (i.e. xpgascy) to obtain the value of annual household energy consumption. In summary, variable energybill is constructed by using Equation (3).

$C_{i t}=\left\{\begin{array}{ll}\text { xpelecy }_{i t}+\text { xpgascy }_{i t}, & \text { if } x_{\text {pduely }} \text { is missing } \\ \text { xpduely }_{i t}, & \text { Otherwise }\end{array}\right.$.

\subsubsection{Age effect}

Research on the relationship between wealth and consumption also shows that the response of consumption to housing wealth is related to age (Baker et al., 1989; Cashin and Mcgranahan, 2006; Ritchie et al., 1981). Compared with young people, old people usually save more on energy. However, the latter may spend more when they feel an increase in housing wealth. Campbell and Cocco (2007) find a large housing wealth effect on consumption for older households but a small effect for young renters. Young people's energy consumption behaviour may not be influenced by their perception of housing wealth. Consequently, the housing wealth effect is weaker among younger households than older households (Sierminska and Takhtamanova, 2012). This behaviour is often referred to as the direct channel of wealth effect, that is, consumptions of older households are more responsive to wealth change than younger households (Gourinchas and Parker, 2002; Juster et al., 2006; Lehnert, 2004). To investigate this age effect, we included dummy variable old, which is equals to 1 for those aged 60 or above, as shown in Equation (2).

\subsubsection{Energy conservation attitude}

Energy conservation attitude is another factor that may affect energy consumption. However, findings on the relationship between energy conservation attitude and energy consumption are mixed. On the one hand, many studies claim that the link between conservative attitudes and energy conservation behaviour is weak (Ritchie et al., 1981; Uutela, 1994; Vringer et al., 2007). Solely changing conservative attitudes receives little energy conservation payoffs. On the other hand, there are empirical evidence supports this relationship. For example, Brandon and Lewis (1999) find that positive environmental attitudes help households improve their energy conservation actions. Aydin et al. (2018) find that energy-conservative households tend 
to reduce their energy consumption when receiving consumption feedback. Sapci and Considine (2014) find strong evidence in the US that environmentally concerned households have significantly low levels of energy consumption. Another recent study in Australia finds that households with positive environmental conservation attitudes have significantly less water consumption (Willis et al., 2011). In addition, many studies find that even without feedback mechanism, conservative attitudes can independently predict energy-conservative behaviour (Sapci and Considine, 2014; Thompson and Barton, 1994). Existing findings seem to be context specific, and empirical evidence from the UK is lacking. Thus, we consider energy conservation attitude in our models to bridge this gap in the literature.

The IP survey has 11 questions to collect information about the participants' environmental habits. The questions are as follows. How often do you (1) leave your TV on standby for the night, (2) keep the tap running while you brush your teeth, (3) switch off lights in rooms that are not being used, (4) put more clothes on when you feel cold rather than turning the heater on or increasing its temperature, (5) decide not to buy something because you feel it has too much packaging, (6) buy recycled paper products (such as toilet paper or tissue), (7) use your own shopping bag when shopping, (8) use public transport (e.g. bus or train) rather than a private vehicle, (9) walk or cycle for short journeys less than 2 or 3 miles, (10) car-share with others who need to make a similar journey or (11) take fewer flights when possible? The answers to all questions are coded in the same way: 1 =always; 2 = very often; $3=$ quite often; $4=$ not very often; $5=$ never. As a value of 1,2 or 3 is an evidence of the corresponding habit, we recoded each variable to be a dummy variable that is equals to 1 if the original values are less than 4 and zero otherwise. An environmental protection attitude score is calculated as follows:

$\operatorname{Score}_{i}=\sum_{k=3}^{11} \operatorname{habit}(k)-\sum_{k=1}^{2} \operatorname{habit}(k)$.

We used the sum of the scores of good habits (i.e. habits [3] through [11]) minus the sum of the scores of bad habits (i.e. habits [1] and [2]) to form an environmental habit score for each participant. To obtain a robust measurement, we calculated the environmental protection attitude scores for four waves between 2011 and $2014^{5}$. The participant is classified as energy conservative (i.e. Conservative $=1$ ) if the score is above median level (i.e. 3 in our sample) in all four waves. We included this energyconservative dummy, conservative, in Equation (2).

\subsubsection{Confidence in financial situation}

Psychological research suggests that confidence has significant influence on our decisions (Estes and Hosseini, 1988; Petrusic and Baranski, 2003; Sniezek, 1992), particularly on financial decisions (Carroll et al., 1994; Ludvigson, 2004; Shiller, 2015). Consumer confidence is related to household consumption (Mishkin, 1978). Previous changes in confidence have explanatory power for current consumption (Carroll et al., 1994). At the aggregate level, confidence can even moderate the effect of housing and financial wealth on household consumption (Fereidouni and Tajaddini, 2017). However, no evidence on its effect on energy consumption has been found yet. Our macro-level analysis reveals that market sentiment (i.e. over-confidence or under-confidence) has a

\footnotetext{
${ }^{5}$ The questions on environmental conservation attitudes are discontinued after 2014.
} 
significant impact on energy consumption as a whole. Will this relationship hold at the individual level? To answer this question, a reliable measurement of sentiment on the household or individual level is needed. We use the confidence in financial situation as the measurement of confidence because of the important role that financial situation plays in spending decisions. We assume that if an individual is less confident in her financial situation, then she will save on energy consumption. However, an increase in housing wealth may boost her confidence in future financial situations and subsequently cause her to spend more on energy.

The measurement of confidence in financial situation, $S$ fut, is derived from a question regarding the respondent's assessment of her finance situation. The variable takes the value of 1 if the answer is 'finding it quite difficult' or 'finding it very difficult' and 0 if the answer is 'living comfortably', 'doing alright' or 'just about getting by'. In other words, $S \_f u t$ is equal to 1 if the respondent believes that her future finance situation will be worse off and 0 otherwise.

\subsubsection{Framing effects}

We then investigated the framing effect of payment methods on energy consumption. Behavioural economic studies have shown that individuals' decisionmaking depends on the way options are presented or 'framed' (Kahneman, 2003; Tversky and Kahneman, 1981, 1986). Framing effect presents when people's response varies when the same information is differently framed. For example, consumer spending is significantly affected by the framing methods of retailers (Darke and Chung, 2005; DelVecchio et al., 2007; Jia et al., 2018). Therefore, energy consumers are also likely responsive to the framing effect.

Our IP dataset presents a unique opportunity to study this effect. In the UK, an individual can pay gas and electric bills either separately or in a combined bill. People who make combined payments may see a bigger number on their bill payment than when paying separately. They consequently have more energy bill pressure and consume less thereafter. However, as they feel an increase in housing wealth, they will consume more than those who use separate payment methods. To verify the framing effect, we introduce a dummy variable, combined_bill, which is equals to 1 if the respondent combines her electricity and gas expenses in one bill and 0 otherwise.

We also included variables to control for key social, economic and demographic factors. These variables include gender (male or female), ncars (number of cars owned by household), hheat (whether accommodation is warm enough in winter), hhsize (number of people in household), hsbeds (number of bedrooms), owner (whether a property is owned outright/with mortgage) and employ (whether in paid employment). The final model to be estimated is given below 6 .

\footnotetext{
${ }^{6}$ Variable conservation was calculated by using the data between 2011 and 2014 (i.e. all data available for energy conservation calculations). Therefore, the variable remains the same across the sampling period. This assumption is reasonable because people's energy consumption attitude should not change significantly over a few years. As a result, variable conservation does not have the subscript for time. Similarly, gender remains the same across all years.
} 


$$
\frac{C_{i t}}{Y_{i t}}=\alpha+\beta \frac{W_{i t}}{Y_{i t}}+\boldsymbol{\theta}\left[\begin{array}{c}
\text { old }_{i t} \\
\text { conservative }_{i} \\
S_{-} \text {fut }_{\text {,it }} \\
\text { combined_bill }_{i t}
\end{array}\right]+\boldsymbol{\gamma}\left[\begin{array}{c}
\text { old }_{i t} \\
\text { conservative }_{i} \\
S_{-} f_{\text {fut }}, i t \\
\text { combined_bill }_{i t}
\end{array}\right] \cdot \frac{W_{i t}}{Y_{i t}}+\boldsymbol{\varphi}\left[\begin{array}{c}
\text { gender }_{i} \\
\text { ncars }_{i t} \\
\text { hheat }_{i t} \\
\text { hhsize }_{i t} \\
\text { hsbed }_{i t} \\
\text { owner }_{i t} \\
\text { employ }_{i t}
\end{array}\right]+\varepsilon_{i t} .
$$

In Equation (5), $\beta$ captures the direct housing wealth effect on energy consumption and $\gamma$ is a row vector of parameters that reflects the medicating effect from age, energy consumption attitude, financial situation and framing on housing wealth effects. Therefore, Equation (5) models the direct and indirect housing wealth effects on energy consumption. Table 5 presents the definitions and descriptive statistics of the variables used in our final analysis.

\section{[ Insert Table 5 here]}

\subsection{Estimation Strategy}

We firstly estimated Equation (5) via the OLS method after adding time and region dummies to control for the variations over time and across geographic regions. We also calculated clustered standard errors on households to take into account the correlation among individuals from the same household ${ }^{7}$. We then re-estimated Equation (5) by using quantile regression method for the following reasons. Firstly, one important variable missing from Equation (5) is the changes in financial wealth. Related questions are included in the 2010 IP survey, yet the high proportion of invalid inputs renders the variables useless. Without controlling for this important confounding factor, our estimation of the housing wealth effect could be biased. For example, if a household's financial and housing wealth increase at the same time and the financial wealth variable is missing from the equation, then the estimated housing wealth effect will likely be inflated. To address this issue, we devised an alternative, indirect measurement of financial wealth. We sorted respondents into quantiles based on the proportion of spending on energy consumption and analyse their energy consumption responses to housing wealth changes within each quartile. The assumption is that people who have more financial assets generally spend a smaller proportion of their income on energy consumption. Hence, the proportion of spending on energy can serve as a proxy of financial wealth. Although this measurement is not ideal, it suffers less measurement error problems than the original, direct measure of financial wealth. Moreover, this research design allows us to incorporate an important energy consumption issue in our analysis, which is fuel poverty.

Fuel poverty has received substantial concerns in the UK. According to the 2016 Annual Fuel Poverty Statistics Report, 2.38 million households in England are fuel poor, representing approximately $10.6 \%$ of total households. In the past years, the average fuel poverty gap (i.e. the amount needed to meet the basic fuel requirement) has risen from $£ 231$ in 2003 to $£ 371$ in 2014 . Numerous studies have discussed the measurement

\footnotetext{
${ }^{7}$ Although the data were obtained from a panel survey database, panel data methods are unsuitable for our analysis. Specifically, some personal characteristics in our dataset are time invariant, such as energy conservation attitude. These variables will be omitted if a fixed effects panel model is estimated.
} 
of fuel poverty (See, for instance, Hills, 2012; Moore, 2012; Thomson and Snell, 2013). Households who need to spend more than $10 \%$ of their income to pay energy bills are usually defined as in fuel poverty. More recently, fuel poverty in the UK is measured using the low income/high cost indicator. According to the Department of Energy and Climate Change, 'A household is considered to be fuel poor if: they have required fuel costs that are above average (the national median level); were they to spend that amount, they would be left with a residual income below the official poverty line' ${ }^{8}$ In both measures, households who spend a large proportion of their income are directly linked to fuel poverty.

'Absolute poverty' and fuel poverty have a strong association (Healy and Clinch, 2004; Howden-Chapman et al., 2012; Legendre and Ricci, 2015; Palmer et al., 2008). As the basic requirement of energy consumption does not differ significantly among households, income level directly determines the proportion of energy spending out of total income, thus creating a close association with fuel poverty (Healy and Clinch, 2004). Many households are fuel 'vulnerable' in the sense that they fall below the fuel poverty line just after deducting energy expenses out of their income. Retired people, households who rent to live and those with poor house insulation have a high likelihood of becoming fuel vulnerable (Legendre and Ricci, 2015).

Therefore, overlooking fuel poverty risks a superficial interpretation of any identified housing wealth effect on energy consumption. The fuel-vulnerable group should be separately analysed from the rest of the population due to their different energy consumption patterns. They operate below the 'fuel poverty line', which means that housing wealth changes may have a great impact on their energy consumption. When housing wealth increases, they will be tempted to consume more energy, not to be extravagant, but to meet the basic energy needs. The former should be discouraged for energy conservation purposes, whereas the latter should be supported to assure basic social and economic equalities. The findings from such an analysis are particularly important for policymakers, who should strike a balance between social justice and economic efficiency.

Although theories and empirical findings suggest a strong link between the proportion of household income spent on energy and fuel poverty, no hard and fast rule defines fuel poverty line. We opted for a flexible strategy to examine fuel poverty effect. Specifically, we sorted respondents into quantiles based on the ratio between energy consumptions and household income and then analysed energy consumption responses to housing wealth changes within each quantile. Compared with the dummy variable approach (i.e. arbitrarily determine a fuel poverty line), this method can reveal the gradual changes of housing wealth effects as the ratio of energy consumption to household income increases. This approach allows us to examine the relation between housing wealth and energy consumption in each quantile of energy spending and identify the quantile with the highest and lowest housing wealth effects.

\subsection{Empirical Findings and Discussions}

Table 6 presents the OLS regression outputs of five models with energy consumption to income ratio (i.e. $\frac{C}{Y}$ ) as the dependent variable. Model (1) is the baseline

\footnotetext{
${ }^{8} \mathrm{https} / / /$ www.gov.uk/government/collections/fuel-poverty-statistics
} 
model that includes housing wealth to income ratio (i.e. $\frac{W}{Y}$ ) and the wave and region dummies only. Model (2) adds all variables included in Equation (5). Model (5) is the same as Model (2) except that it uses clustered standard error. Models (3) and (4) are intermediate calculations without either the wave and region dummies or the control variables to check the robustness of the findings in Model (5). Overall, Model (5) is the best one in terms of coefficient estimates and model fitting statistics. We then used Model (5)'s specification in the quantile regression analysis. A total of five more models are estimated for the 10th, 25th, 50th, 75th and 90th percentiles, and the results are given in Table 7. The output of Model (5) in Table 6 is also included in the last column of Table 7 for comparison purposes.

The quantile regression outputs show the gradual changes of housing wealth effect across groups with different energy consumption-to-income ratios. Although the overall housing wealth effect is approximately 0.002 in all models included in Table 6 , the quantile models in Table 7 suggest a substantial disparity between the 10th and 90th percentiles of the sample. For example, the housing wealth effect for the most worstoff group (i.e. the 90th percentile) is 0.0069 , which is more than thrice that for the most well-off group (i.e. the 10th percentile). The estimates of these coefficients across the five percentiles show a consistent increasing trend as the proportion of energy consumption in income increases. To further explore this pattern, we also run 99 quantile regressions from the 1 st to the 99th percentile with a $1 \%$ step value. The estimated housing wealth effect in these regressions is plotted in Figure 3. The housing wealth effect remains stable until around the 50th percentile, where it starts to increase steadily and rapidly. It once again stabilised at approximately the 85 th percentile. This evidence is consistent with the definition of fuel poverty by the Department of Energy and Climate Change (i.e. fuel cost is above the national average) and with the statistics reported in the Annual Fuel Poverty Statistics Report (i.e. 10.6\% of the UK households are fuel poor). We conclude that fuel poverty significantly affects housing wealth's effect on energy consumption. Energy-poor households are considerably responsive to the changes of housing wealth when it comes to energy consumption. When energypoor households perceive an increase in their housing wealth, their energy consumption level will go up considerably more than other households.

\section{[ Insert Figure 3 here]}

The quantile regression approach reliably separates the direct housing wealth effects from other energy consumption determinants, as shown in the first row in Table 7. Moreover, it improves the estimation of the indirect effect of housing wealth on energy consumption, as discussed below.

\section{Age Effect}

Elderly residents generally spend less on energy, as indicated by the coefficient estimates of variable Old in Model (5). However, this behaviour mostly comes from the 25th and 50th percentile groups, as shown in the quantile regression outputs of Models (7) and (8). The most well-off and fuel-poor groups seem to consume more if they are aged 60 or above. All else being equal, elderly people need to consume more energy because they tend to spend more time in their houses and require more heating and cooling than young people. Moreover, they want to save on energy (among many other things), as indicated by the significant coefficient estimate of Old in Model (5). 
However, the elderly in the most well-off group have the means to spend as much as they want on energy, whereas the elderly in the worst-off group have to spend a substantial proportion of their income on energy even if they want to save. The only groups who are willing and able to save on energy are the 25th and 50th percentile groups, of which the coefficient estimates of Old is positive.

Age similarly moderates the housing wealth effect. As a whole, although the elderlies are likely to spend more on energy when housing wealth increases, the housing wealth effect is smaller for the worst-off groups (i.e. the 75th and 90th percentiles) because they have a relatively smaller budget to manoeuvre and more financial issues to deal with. When the energy consumption to income ratio goes below the median level, elderly people tend to spend even more of the perceived housing wealth on energy, as suggested by the positive coefficient loadings on variable Old in Models (6) to (8).

\section{Energy Conservation Attitude}

The overall effect of energy conservation attitude on energy consumption is insignificant in Model (5). However, when we analyse this relationship by quantile, the results make more sense. The better-off groups (i.e. the 10th to 50th percentiles) tend to save more on energy consumption if they are classified as energy conservative (i.e. conservative $=1$ ). This finding is in the same vein as those regarding age effect. Even if fuel-poor groups (i.e. the 75th and 90th percentiles) are environmentally conscious, they are unlikely to have the financial means to act upon such a good intention. Consequently, the coefficient estimates in Models (9) and (10) are statistically insignificant. Thus, energy conservation attitude does not have a significant effect on energy consumption in these groups.

However, energy-conservative people will be less affected by the housing wealth effect on energy consumption, and this tendency is stronger among the worstoff groups. The coefficient estimates of the interaction term between conservative and the housing wealth variable is negative in all the quantile regression models in Table 7 , and the largest coefficient loading (in absolute term) is in the 90th percentile model. Intention is easier to be translated to actions even if one's housing wealth level is only perceived to be improved.

\section{Confidence in Financial Situation}

We identified the influence of financial constraints on energy consumption behaviour, in terms of the energy spending out of total income, and the housing wealth effect on energy spending. Firstly, the confidence in one's future financial conditions directly affects energy consumption behaviour. Financially constrained people generally spend less on energy consumption due to their poor finance prospect. As shown in Model (5), people who believe they would have financial difficulty in the future save an average of more than $6 \%$ on energy from their income. This effect is stronger among more financially disadvantaged groups (i.e. the higher percentile groups). For example, the coefficient estimate of $S \_$fut in the 90th percentile model is -0.0244 , which is more than ten times greater than that in the 10th percentile model.

When housing wealth increases, less confident groups (i.e. when $S f u t=1$ ) may experience a boost in their confidence and subsequently spend more on energy. Once 
again, this pattern is much stronger among the worse-off groups. The increase in the housing wealth effect for the 90th percentile group is more than ten times greater than that for the 10th percentile group. This result suggests that confidence in future financial situations has great impact on energy consumption behaviours for the worse-off groups.

\section{Framing Effect}

Compared with those who separately pay bills, people who pay combined bills spend $0.5 \%$ less on energy out of their income. The framing effect assumes that the way options are presented can influence people's decision-making. For example, just displaying real time energy consumption information with in-home displays is not sufficient to encourage energy saving. But changing the time of energy payment to prepaid electricity could effectively stimulate the monitoring of bills and energy conservation activities (Lundgren and Schultzberg, 2019). When people use combined bill payment, the aggregated cost figure might look bigger than each of the separate gas and electricity costs. Consequently, people may perceive a large energy consumption level and consequently lower their consumption thereafter.

The framing effect is a type of 'nudge' that affect people's behaviours without changing economic incentives or forbidding the exercise of freewill. In the context of combined energy bill payment method, it is essentially a psychological pressure that works on a subconscious level to induce people to spend less on energy. Our empirical evidence shows that this nudge works like a double-edged sword. For better-off groups (i.e. the 10th to 50th percentile groups), the nudge effect works as expected when housing wealth increases. However, for the worse-off groups (i.e. the 75th and 90th percentiles), the long experience pressure on energy spending will boost the housing wealth effect. Thus, the positive relationship between housing wealth and energy consumption is strong for worse-off groups who use a combined bill payment method.

\section{[ Insert Table 6 here ]}

[ Insert Table 7 here]

\section{Conclusion and Policy Implications}

This study investigates the housing wealth effect on energy consumption. Our theoretical framework combines both macro- and micro- level analyses, and considers both rational and irrational energy consumption decision making. The framework can reliably identify the net effect of housing wealth on energy consumption. The use of five waves from a large household panel survey dataset in our empirical analysis also allows our findings to be generalized to a wide class of settings. Therefore, the theoretical framework and empirical strategies in this paper can be used to ensure internal and external validity in future research on energy consumption and housing wealth.

Our research also contributes to the behavioural science literature by providing valuable field evidence. One of the most challenging aspects of behavioural research is the poor external validity of experimental evidence (DellaVigna, 2009; Galizzi and Navarro-Martinez, 2019; Levitt and List, 2008). Field evidence is preferred but difficult 
to obtain. This is particularly true for studies of decision processes that are difficult to replicate in experimental settings, such as housing or energy consumption decisions. Our behavioural investigation into the role of market sentiment and framing effect in energy consumption decisions are based on observational data collected from real decision makers. It adds value to the literature of behavioural housing and energy policy studies.

Using macroeconomic data, our long-run investigation reveals a positive relationship between housing wealth and residential energy consumption between 1995 and 2016 in the UK. We further explore this relationship using data at the household level. By leveraging a large nationwide household survey data across five waves, we also confirm the significant association between housing wealth and energy consumption at the micro level. As the perception of housing value increases, people tend to increase their energy consumption. This effect varies in accordance with respondents' age, financial situation and environmental awareness. We also investigate the role of framing effect in moderating the housing wealth effect on residential energy consumption. Framing effect, represented by whether households make combined bill payment or separate bill payment, affects energy consumption. Combined bill payers save more on energy because they are more likely to feel 'pressured' by the big amount on their bill. However, such people have stronger housing wealth effect. They increase greater marginal energy spending than others who face the same amount of housing wealth increase.

Our household-level analysis also sheds light on the intriguing relationship among housing wealth, residential energy consumption and fuel poverty. By looking into different quantiles of the energy consumption distribution, we run the quantile regression on the 5th, 25th, 50th, 75th and 95th percentiles and identified an interesting pattern of the varying housing wealth effect. Overall, the effect becomes stronger as the energy to income ratio increases. When energy-poor households perceive an increase in their housing wealth, their energy consumption level will go up considerably more than other households. This is consistent with the energy consumption pattern that we observed in Figure 1. However, this effect is mainly due to their needs to bring their energy consumption to the normal level, as many of them might have been operating below the 'fuel poverty line'. Such increase in energy consumption should not be discouraged. However, policy makers need to be wary of the externality of such an effect. Cashing out housing wealth appreciation is not straightforward; sometimes, it is not even possible. This fact is particularly true for financially constrained households, such as the energy-poor group. If they act upon the 'feeling rich' psychological effect resulting from housing wealth appreciation, their financial and energy consumption situations could worsen in the future, with a larger energy bill down the road. By contrast, during financial downturns, local governments and support groups should also take into account the additional psychological pressure from housing wealth depreciation on energy consumptions among these households.

In summary, the relationship between housing wealth and residential energy consumption varies in terms of building and household characteristics. Psychological factors also play a significant role in moderating such a relationship. This analysis provides empirical evidence from the UK that shed light on the connection between housing wealth and residential energy consumption. The findings are helpful in the 
design and delivery of energy consumption policies that can be economically beneficial and socially fair.

\section{Reference}

1. Aladangady, A., 2017. Housing Wealth and Consumption: Evidence from Geographically Linked Microdata. Am Econ Rev 107, 3415-3446.

2. Ando, A., Modigliani, F., 1963. The Life-Cycle Hypothesis of Saving Aggregate Implications and Tests. Am Econ Rev 53, 55-84.

3. Attanasio, O.P., Blow, L., Hamiltonww, R., Leicester, A., 2009. Booms and Busts: Consumption, House Prices and Expectations. Economica 76, 20-50.

4. Aydin, E., Brounen, D., Kok, N., 2018. Information provision and energy consumption: Evidence from a field experiment. Energ Econ 71, 403-410.

5. Baker, P., Blundell, R., Micklewright, J., 1989. Modeling Household Energy Expenditures Using Micro-Data. Econ J 99, 720-738.

6. Barrell, R., Costantini, M., Meco, I., 2015. Housing wealth, financial wealth, and consumption: New evidence for Italy and the UK. Int Rev Financ Anal 42, 316-323.

7. Bostic, R., Gabriel, S., Painter, G., 2009. Housing wealth, financial wealth, and consumption: New evidence from micro data. Regional Science and Urban Economics 39, 79-89.

8. Brandon, G., Lewis, A., 1999. Reducing household energy consumption: a qualitative and quantitative field study. Journal of Environmental Psychology $19,75-85$.

9. Brounen, D., Kok, N., Quigley, J.M., 2012. Residential energy use and conservation: Economics and demographics. European Economic Review 56, 931-945.

10. Campbell, J.Y., Cocco, J.F., 2007. How do house prices affect consumption? Evidence from micro data. Journal of Monetary Economics 54, 591-621.

11. Carroll, C.D., 1992. The Buffer-Stock Theory of Saving - Some Macroeconomic Evidence. Brookings Pap Eco Ac, 61-135.

12. Carroll, C.D., Fuhrer, J.C., Wilcox, D.W., 1994. Does Consumer Sentiment Forecast Household Spending - If So, Why. Am Econ Rev 84, 1397-1408.

13. Carroll, C.D., Otsuka, M., Slacalek, J., 2011. How Large Are Housing and Financial Wealth Effects? A New Approach. Journal of Money Credit and Banking 43, 55-79.

14. Cashin, D.B., Mcgranahan, L., 2006. Household energy expenditures, 19822005. Chic. Fed Lett.: Fed. Reserve Bank Chic 227, 1-5.

15. Chen, J., 2006. Re-evaluating the association between housing wealth and aggregate consumption: New evidence from Sweden. J Hous Econ 15, 321-348.

16. Chiang, T., Mevlevioglu, G., Natarajan, S., Padget, J., Walker, I., 2014. Inducing sub conscious energy behaviour through visually displayed energy information: A case study in university accommodation. Energy and Buildings 70, 507-515.

17. Darke, P.R., Chung, C.M.Y., 2005. Effects of pricing and promotion on consumer perceptions: it depends on how you frame it. J Retailing 81, 35-47.

18. Deaton, A., 1992. Understanding consumption / Angus Deaton. Clarendon Press ; Oxford University Press, Oxford [England] : New York.

19. DellaVigna, S., 2009. Psychology and Economics: Evidence from the Field. J Econ Lit 47, 315-372. 
20. DelVecchio, D., Krishnan, H.S., Smith, D.C., 2007. Cents or percent? The effects of promotion framing on price expectations and choice. J Marketing 71, 158-170.

21. Dolmas, J., 2003. A note on the potential pitfalls in estimating a 'wealth effect' on consumption from aggregate data. Econ Lett 78, 437-441.

22. Druckman, A., Jackson, T., 2008. Household energy consumption in the UK: A highly geographically and socio-economically disaggregated model. Energ Policy 36, 3177-3192.

23. Estes, R., Hosseini, J., 1988. The Gender Gap on Wall Street - an EmpiricalAnalysis of Confidence in Investment Decision-Making. J Psychol 122, 577590.

24. Estiri, H., 2014. Building and household X-factors and energy consumption at the residential sector A structural equation analysis of the effects of household and building characteristics on the annual energy consumption of US residential buildings. Energ Econ 43, 178-184.

25. Fereidouni, H.G., Tajaddini, R., 2017. Housing Wealth, Financial Wealth and Consumption Expenditure: The Role of Consumer Confidence. J Real Estate Financ 54, 216-236.

26. Galizzi, M.M., Navarro-Martinez, D., 2019. On the External Validity of Social Preference Games: A Systematic Lab-Field Study. Management Science 65, 976-1002.

27. Gan, J., 2010. Housing Wealth and Consumption Growth: Evidence from a Large Panel of Households. Rev Financ Stud 23, 2229-2267.

28. Gatersleben, B., Steg, L., Vlek, C., 2002. Measurement and determinants of environmentally significant consumer behavior. Environ Behav 34, 335-362.

29. Gillingham, K., Tsvetanov, T., 2018. Nudging energy efficiency audits: Evidence from a field experiment. Journal of Environmental Economics and Management 90, 303-316.

30. Gourinchas, P.O., Parker, J.A., 2002. Consumption over the life cycle. Econometrica 70, 47-89.

31. Healy, J.D., Clinch, J.P., 2004. Quantifying the severity of fuel poverty, its relationship with poor housing and reasons for non-investment in energy-saving measures in Ireland. Energ Policy 32, 207-220.

32. Hills, J., 2012. Getting the measure of fuel poverty, Final Report of the Fuel Poverty Review.

33. Howden-Chapman, P., Viggers, H., Chapman, R., O'Sullivan, K., Barnard, L.T., Lloyd, B., 2012. Tackling cold housing and fuel poverty in New Zealand: A review of policies, research, and health impacts. Energ Policy 49, 134-142.

34. Huang, W.H., 2015. The determinants of household electricity consumption in Taiwan: Evidence from quantile regression. Energy 87, 120-133.

35. Iacoviello, M., 2011. Housing Wealth and Consumption Board of Governors of the Federal Reserve System International Finance Discussion Papers 1027 August 2011.

36. Iyke, B.N., 2015. Electricity consumption and economic growth in Nigeria: A revisit of the energy-growth debate. Energ Econ 51, 166-176.

37. Jackson, T., Papathanasopoulou, E., Bradley, P., Druckman, A., 2007. Attributing UK Carbon Emissions to Functional Consumer Needs: methodology and pilot results, RESOLVE Working Paper 01-07, University of Surrey. 
38. Jia, H., Yang, S., Lu, X.H., Park, C.W., 2018. Do Consumers Always Spend More When Coupon Face Value is Larger? The Inverted U-Shaped Effect of Coupon Face Value on Consumer Spending Level. J Marketing 82, 70-85.

39. Juster, F.T., Lupton, J.P., Smith, J.P., Stafford, F., 2006. The decline in household saving and the wealth effect. Rev Econ Stat 88, 20-27.

40. Kahneman, D., 2003. Maps of bounded rationality: Psychology for behavioral economics. Am Econ Rev 93, 1449-1475.

41. Khandker, S.R., Barnes, D.F., Samad, H.A., 2012. Are the energy poor also income poor? Evidence from India. Energ Policy 47, 1-12.

42. Kishor, N.K., 2007. Does consumption respond more to housing wealth than to financial market wealth? if so, why? J Real Estate Financ 35, 427-448.

43. Legendre, B., Ricci, O., 2015. Measuring fuel poverty in France: Which households are the most fuel vulnerable? Energ Econ 49, 620-628.

44. Lehnert, A., 2004. Housing, consumption, and credit constraints. Board of Governors of the Federal Reserve System (U.S.).

45. Levitt, S.D., List, J.A., 2008. Homo economicus evolves. Science 319, 909-910.

46. Ludvigson, S.C., 2004. Consumer confidence and consumer spending. J Econ Perspect 18, 29-50.

47. Ludwig, A., Sløk, T., 2002. The Impact of Changes in Stock Prices and House Prices on Consumption in OECD Countries. IMF Working Paper No. 02/1 January 2002.

48. Lundgren, B., Schultzberg, M., 2019. Application of the economic theory of self-control to model energy conservation behavioral change in households. Energy 183, 536-546.

49. Lynham, J., Nitta, K., Saijo, T., Tarui, N., 2016. Why does real-time information reduce energy consumption? Energ Econ 54, 173-181.

50. Miller, J.I., Ratti, R.A., 2009. Crude oil and stock markets: Stability, instability, and bubbles. Energ Econ 31, 559-568.

51. Mishkin, F.S., 1978. Consumer Sentiment and Spending on Durable Goods. Brookings Pap Eco Ac, 217-231.

52. Moore, R., 2012. Definitions of fuel poverty: Implications for policy. Energ Policy 49, 19-26.

53. Ndiaye, D., Gabriel, K., 2011. Principal component analysis of the electricity consumption in residential dwellings. Energy and Buildings 43, 446-453.

54. Nye, M., Whitmarsh, L., Foxon, T., 2010. Sociopsychological perspectives on the active roles of domestic actors in transition to a lower carbon electricity economy. Environment and Planning A 42, 697-714.

55. Odusami, B.O., 2010. To consume or not: How oil prices affect the comovement of consumption and aggregate wealth. Energ Econ 32, 857-867.

56. Paiella, M., 2007. Does wealth affect consumption? Evidence for Italy. J Macroecon 29, 189-205.

57. Palmer, G., MacInnes, T., Kenway, P., 2008. Cold and Poor: An Analysis of the Link Between Fuel Poverty and Low Income. Report New Policy Institute.

58. Petrusic, W.M., Baranski, J.V., 2003. Judging confidence influences decision processing in comparative judgments. Psychon B Rev 10, 177-183.

59. Rahut, D.B., Behera, B., Ali, A., Marenya, P., 2017. A ladder within a ladder: Understanding the factors influencing a household's domestic use of electricity in four African countries. Energ Econ 66, 167-181.

60. Rao, M.N., Reddy, B.S., 2007. Variations in energy use by Indian households: An analysis of micro level data. Energy 32, 143-153. 
61. Revell, K., 2014. Estimating the environmental impact of home energy visits and extent of behaviour change. Energ Policy 73, 461-470.

62. Ritchie, J.R.B., Mcdougall, G.H.G., Claxton, J.D., 1981. Complexities of Household Energy-Consumption and Conservation. J Consum Res 8, 233-242.

63. Sanchez-Sutil, F., Cano-Ortega, A., Hernandez, J.C., Rus-Casas, C., 2019. Development and Calibration of an Open Source, Low-Cost Power Smart Meter Prototype for PV Household-Prosumers. Electronics 8, 878.

64. Sapci, O., Considine, T., 2014. The link between environmental attitudes and energy consumption behavior. J Behav Exp Econ 52, 29-34.

65. Shahbaz, M., Solarin, S.A., Hammoudeh, S., Shahzad, S.J.H., 2017. Bounds testing approach to analyzing the environment Kuznets curve hypothesis with structural beaks: The role of biomass energy consumption in the United States. Energ Econ 68, 548-565.

66. Shiller, R.J., 2015. Irrational Exuberance, STU - Student edition, 3 ed. Princeton University Press.

67. Sierminska, E., Takhtamanova, Y., 2012. Financial and Housing Wealth and Consumption Spending: Cross-Country and Age Group Comparisons. Housing Studies 27, 685-719.

68. Sniezek, J.A., 1992. Groups under Uncertainty - an Examination of Confidence in Group Decision-Making. Organ Behav Hum Dec 52, 124-155.

69. Sonje, A.A., Casni, A.C., Vizek, M., 2012. Does housing wealth affect private consumption in European post-transition countries? Evidence from linear and threshold models. Post-Communist Econ 24, 73-85.

70. Swan, L.G., Ugursal, V.I., 2009. Modeling of end-use energy consumption in the residential sector: A review of modeling techniques. Renewable \& Sustainable Energy Reviews 13, 1819-1835.

71. Takama, T., Tsephel, S., Johnson, F.X., 2012. Evaluating the relative strength of product-specific factors in fuel switching and stove choice decisions in Ethiopia. A discrete choice model of household preferences for clean cooking alternatives. Energ Econ 34, 1763-1773.

72. Thompson, S.C.G., Barton, M.A., 1994. Ecocentric and Anthropocentric Attitudes toward the Environment. Journal of Environmental Psychology 14, 149-157.

73. Thomson, H., Snell, C., 2013. Quantifying the prevalence of fuel poverty across the European Union. Energ Policy 52, 563-572.

74. Tso, G.K.F., Guan, J., 2014. A multilevel regression approach to understand effects of environment indicators and household features on residential energy consumption. Energy 66, 722-731.

75. Tversky, A., Kahneman, D., 1981. The Framing of Decisions and the Psychology of Choice. Science 211, 453-458.

76. Tversky, A., Kahneman, D., 1986. Rational Choice and the Framing of Decisions. J Bus 59, S251-S278.

77. Uutela, H.M., 1994. The everyday energy use and lifestyles of families in single family households, in: Arvola, A., Rautavaara, E., Uutela, A. (Eds.), Energy and the Consumer, Helsinki: Ministry of Trade and Industry, Energy Department.

78. Valenzuela, C., Valencia, A., White, S., Jordan, J.A., Cano, S., Keating, J., Nagorski, J., Potter, L.B., 2014. An analysis of monthly household energy consumption among single-family residences in Texas, 2010. Energ Policy 69, 263-272. 
79. Valor, C., Escudero, C., Labajo, V., Cossent, R., 2019. Effective design of domestic energy efficiency displays: A proposed architecture based on empirical evidence. Renewable \& Sustainable Energy Reviews 114.

80. Vringer, K., Aalbers, T., Blok, K., 2007. Household energy requirement and value patterns. Energ Policy 35, 553-566.

81. Willis, R.M., Stewart, R.A., Panuwatwanich, K., Williams, P.R., Hollingsworth, A.L., 2011. Quantifying the influence of environmental and water conservation attitudes on household end use water consumption. J Environ Manage 92, 19962009.

82. Wood, G., Day, R., Creamer, E., van der Horst, D., Hussain, A., Liu, S.L., Shukla, A., Iweka, O., Gaterell, M., Petridis, P., Adams, N., Brown, V., 2019. Sensors, sense-making and sensitivities: UK household experiences with a feedback display on energy consumption and indoor environmental conditions. Energy Research \& Social Science 55, 93-105.

83. Wood, G., Newborough, M., 2003. Dynamic energy-consumption indicators for domestic appliances: environment, behaviour and design. Energy and Buildings $35,821-841$. 
Figure 1. Energy expenditure as a percentage of total household expenditure in the UK

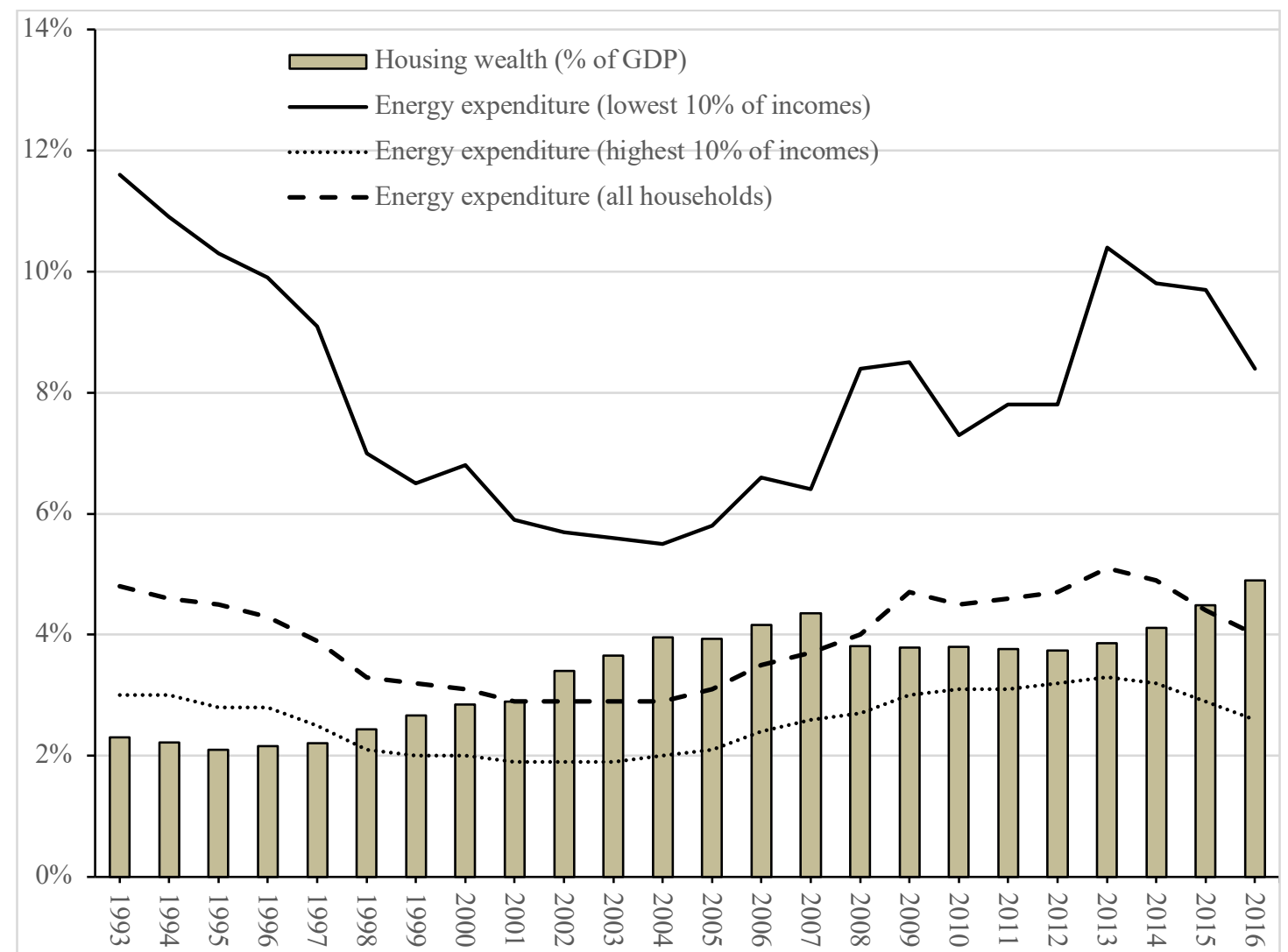

Data source: Office of Gas and Electricity Markets and Office for National Statistics, UK. 
Figure 2. Consumption, Wealth, and Market Sentiment

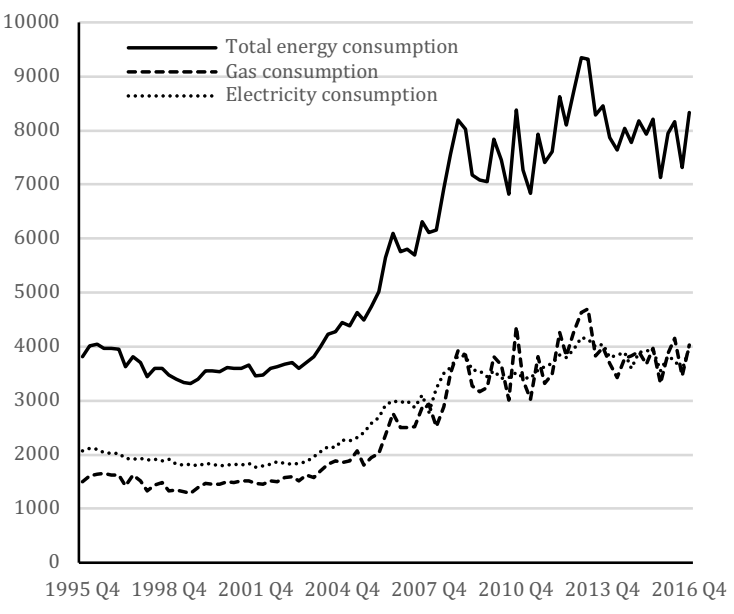

Figure 1a: Energy Consumptions

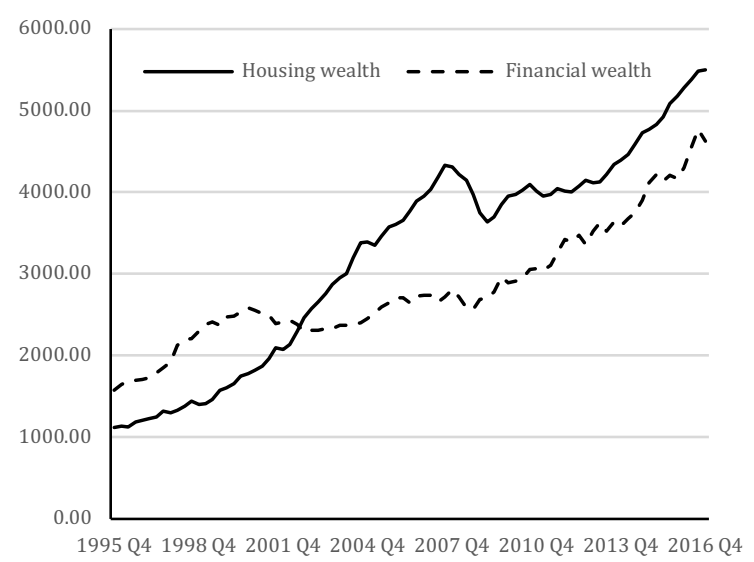

Figure 1c: Wealth

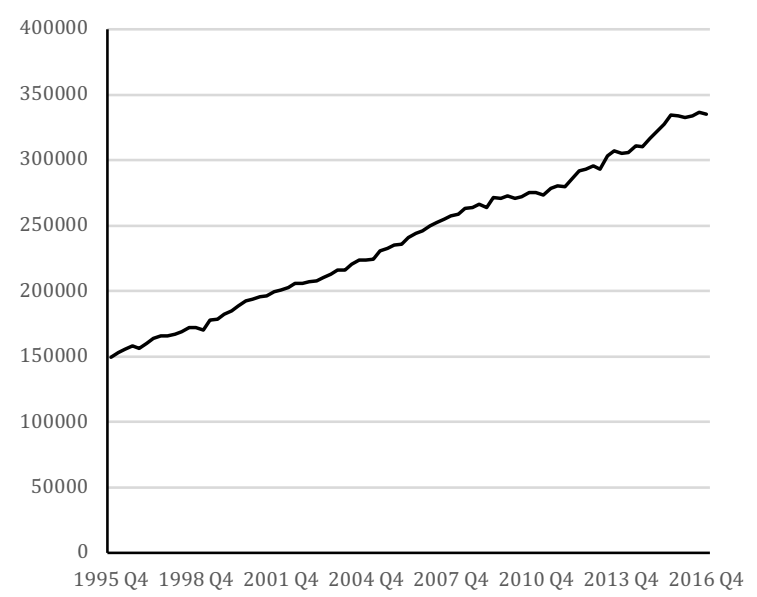

Figure 1e: Household disposable Income

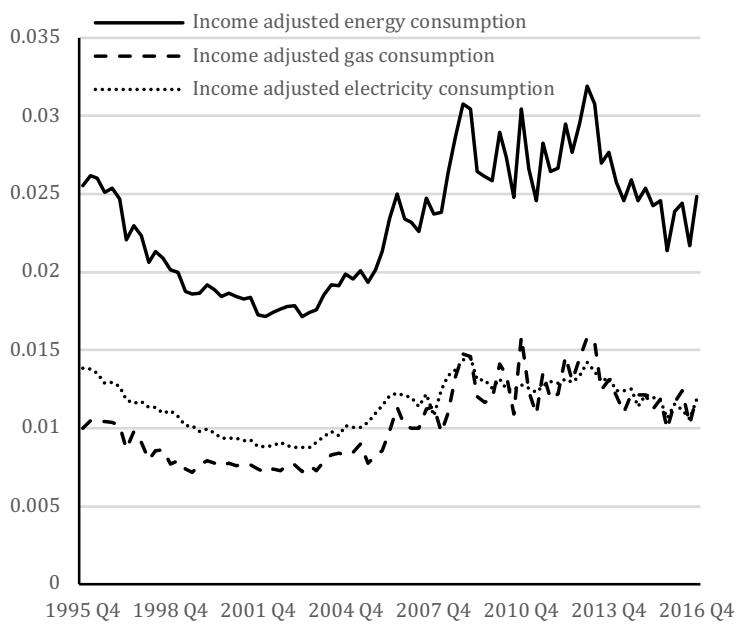

Figure 1b: Income-adjusted Energy Consumptions

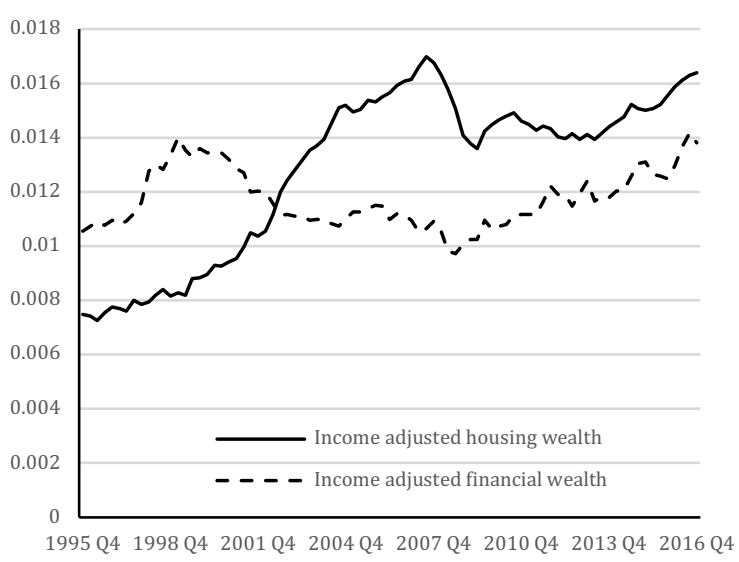

Figure 1d: Income-adjusted Wealth

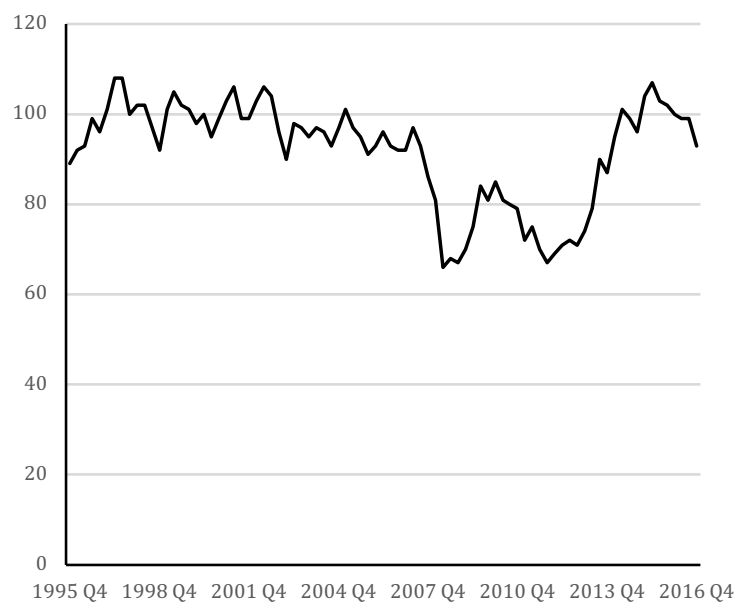

Figure 1f: Consumer Confidence Index 
Figure 3. Quantile regression estimation of housing wealth effect on energy consumption ( $1^{\text {st }}$ to $99^{\text {th }}$ percentile)

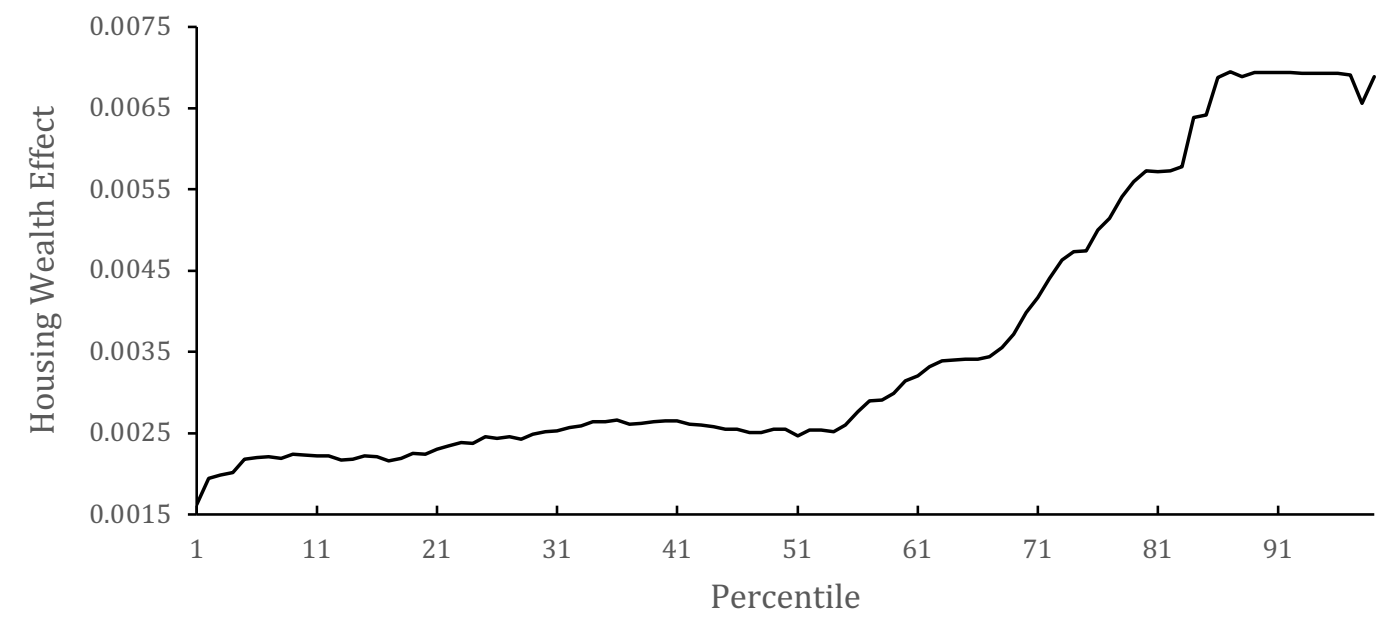


Table 1: Housing wealth and financial wealth in the UK

\begin{tabular}{c|cc|cc}
\hline \multirow{2}{*}{ Period } & $\begin{array}{c}\text { Housing } \\
\text { wealth }\end{array}$ & $\begin{array}{c}\text { Financial } \\
\text { wealth }\end{array}$ & $\begin{array}{c}\text { Housing } \\
\text { wealth }\end{array}$ & $\begin{array}{c}\text { Financial } \\
\text { wealth }\end{array}$ \\
\cline { 2 - 5 } (\% of GDP) & \multicolumn{2}{|c|}{ (net, £ billion) $^{* *}$} \\
\hline $1936-1946$ & 0.85 & 4.17 & -- & -- \\
$1946-1956$ & 1.05 & 3.16 & -- & -- \\
$1956-1966$ & 1.08 & 2.65 & -- & -- \\
$1966-1976$ & 1.65 & 2.14 & -- & -- \\
$1976-1986$ & 2.01 & 1.76 & -- & -- \\
$1986-1996$ & 2.72 & 2.57 & -- & -- \\
$1996-2006$ & 3.02 & 3.37 & -- & -- \\
$2006-2008$ & 4.26 & 3.07 & 3,537 & 1,043 \\
$2008-2010$ & 3.80 & 2.71 & 3,379 & 1,093 \\
$2010-2012$ & 3.79 & 3.05 & 3,528 & 1,309 \\
$2012-2014$ & 3.80 & 3.16 & 3,806 & 1,564 \\
$2014-2016$ & 4.12 & 3.55 & 4,506 & 1,630 \\
$2016-2018 * * *$ & -- & -- & 5,090 & 2,124 \\
\hline
\end{tabular}

* Data Source: 'Economic Statistics Transformation Programme: Historical estimates of financial accounts and balance sheets', Office for National Statistics, UK, 2016.

** Data Source: Office for National Statistics, UK, 2019.

*** Provisional data released by the Office for National Statistics on 5 December 2019.

Table 2: Social-economic statistics for selected OECD countries

\begin{tabular}{lcccccc}
\hline & $\begin{array}{c}\text { Lift } \\
\text { expectancy } \\
\text { (years, } \\
\mathbf{2 0 1 7 )}\end{array}$ & $\begin{array}{c}\text { Adult with } \\
\text { tertiary } \\
\text { education } \\
\mathbf{( \% , 2 0 1 8 )}\end{array}$ & $\begin{array}{c}\text { Homeowne- } \\
\text { rship rate } \\
\mathbf{( \% , 2 0 1 8 )}\end{array}$ & $\begin{array}{c}\text { GDP per } \\
\text { capita (USD } \\
\mathbf{2 0 1 9 )}\end{array}$ & $\begin{array}{c}\text { Unemploy- } \\
\text { ment rate } \\
\mathbf{( \% , 2 0 1 8 )}\end{array}$ & $\begin{array}{c}\text { Energy } \\
\text { price index } \\
\mathbf{2 0 1 9 2 2} \\
\mathbf{2 0 1 5}=\mathbf{1 0 0})\end{array}$ \\
\hline Australia & 83 & 46 & 63 & 54752 & 5.30 & 98.7 \\
Canada & 82 & 58 & 69 & 50967 & 5.83 & 120.5 \\
France & 83 & 37 & 62 & 47823 & 9.03 & 113.2 \\
Germany & 81 & 29 & 44 & 55737 & 3.40 & 96.7 \\
UK & 81 & 46 & 65 & 48092 & 4.02 & 106.4 \\
USA & 79 & 47 & 63 & 65127 & 3.90 & 100.8 \\
\hline
\end{tabular}

Data source: OECD Data (https://data.oecd.org). 
Table 3. Data source and transformation

\begin{tabular}{|c|c|c|c|c|c|c|}
\hline $\begin{array}{l}\text { Variable } \\
\text { Name }\end{array}$ & Definition & Source & Mean & S.D. & Min & Max \\
\hline TCON & Total consumption (£million, SA) & $\begin{array}{l}\text { ONS UK consumer trends } \\
\text { UK domestic total: Sum of durable, semi-durable and non-durable goods } \\
\text { plus services. }\end{array}$ & 219160.20 & 48508.84 & 134577 & 310643 \\
\hline GCON & Goods consumption (£million, SA) & $\begin{array}{l}\text { ONS UK consumer trends } \\
\text { Total for goods: Sum of durable, semi-durable and non-durable goods. }\end{array}$ & 94065.60 & 19270.74 & 59504 & 128249 \\
\hline SCON & Services consumption (£million, SA) & $\begin{array}{l}\text { ONS UK consumer trends } \\
\text { Services: Clothing and footwear, housing, water, electricity, gas and other } \\
\text { fuels, furnishing, household equipment and routine maintenance of the } \\
\text { house, financial services, transport and communication, restaurants and } \\
\text { hotels, package holiday, education, social protection, recreation and } \\
\text { cultural services. }\end{array}$ & 125094.60 & 29294.73 & 75073 & 182394 \\
\hline ECON & Total energy consumption & $\begin{array}{l}\text { ONS UK consumer trends } \\
\text { Electricity, gas and other fuels }\end{array}$ & 5681.52 & 1989.06 & 3316 & 9347 \\
\hline GAS & Gas consumption & $\begin{array}{l}\text { ONS UK consumer trends } \\
\text { Gas }\end{array}$ & 2559.81 & 1070.31 & 1284 & 4698 \\
\hline ELEC & Electricity consumption & $\begin{array}{l}\text { ONS UK consumer trends } \\
\text { Electricity }\end{array}$ & 2792.98 & 859.97 & 1768 & 4167 \\
\hline HW & Housing wealth (£million) & $\begin{array}{l}\text { ONS UK national balance sheet } \\
\text { Table } 10 \text { Housing wealth }=\text { dwellings }+ \text { buildings other than dwellings }+ \\
\text { other structures }+ \text { land }\end{array}$ & 3227.54 & 1302.42 & 1119.94 & 5500.49 \\
\hline FW & Financial wealth (£million) & ONS UK flow of funds & 2823.30 & 737.75 & 1577.38 & 4770.58 \\
\hline INC & Gross disposable income (£million, SA) & ONS UK economics account HNISH & 240416.50 & 54903.56 & 149434 & 336586 \\
\hline CCI & UK consumer confidence index & GfK Consumer Confidence Index downloaded from Bloomberg & 91.73 & 11.57 & 66 & 108 \\
\hline
\end{tabular}


Table 4. VECM estimation results

\begin{tabular}{|c|c|c|c|c|c|c|}
\hline & $\begin{array}{c}\text { Total } \\
\text { consumption }\end{array}$ & $\begin{array}{c}\text { Goods } \\
\text { Consumption }\end{array}$ & $\begin{array}{c}\text { Services } \\
\text { Consumption }\end{array}$ & $\begin{array}{l}\text { Total Energy } \\
\text { Consumption }\end{array}$ & $\begin{array}{c}\text { Energy Consumption } \\
\text { - Gas }\end{array}$ & $\begin{array}{c}\text { Energy Consumption } \\
\text { - Electricity }\end{array}$ \\
\hline \multicolumn{7}{|l|}{ Long-run equilibrium } \\
\hline \multirow[t]{2}{*}{ Housing wealth } & 2.1840 & 2.1768 & $3.4005 * * *$ & $1.0295 * *$ & $0.8829 * *$ & $0.3002 *$ \\
\hline & $(1.395)$ & $(2.548)$ & $(0.584)$ & $(0.491)$ & $(0.364)$ & $(0.166)$ \\
\hline \multirow[t]{2}{*}{ Financial wealth } & -2.8332 & -7.0214 & 1.4602 & -0.6408 & -0.2708 & -0.3533 \\
\hline & $(4.147)$ & $(7.575)$ & $(1.735)$ & $(1.460)$ & $(1.083)$ & $(0.495)$ \\
\hline \multirow[t]{2}{*}{ Consumer confidence } & $0.0030 * * *$ & $0.0048 * * *$ & $0.0014 * * *$ & $0.0006^{* * *}$ & $0.0005 * * *$ & $0.0002 * * *$ \\
\hline & $(0.000)$ & $(0.001)$ & $(0.000)$ & $(0.000)$ & $(0.000)$ & $(0.000)$ \\
\hline \multirow[t]{2}{*}{ Constant } & 0.6439 & 0.0081 & 0.3310 & -0.0393 & -0.0433 & -0.0069 \\
\hline & . & . & . & . & . & . \\
\hline \multicolumn{7}{|l|}{ Short-run adjustment } \\
\hline \multirow[t]{2}{*}{ Consumption } & $-0.1249 * * *$ & -0.0145 & $-0.2034 * * *$ & -0.0180 & -0.0184 & -0.0157 \\
\hline & $(0.041)$ & $(0.012)$ & $(0.053)$ & $(0.020)$ & $(0.021)$ & $(0.018)$ \\
\hline \multirow[t]{2}{*}{ Housing wealth } & $-0.0059 * * *$ & $-0.0033 * * *$ & $-0.0131 * * *$ & $-0.0164 * * *$ & $-0.0220 * * *$ & $-0.0479 * * *$ \\
\hline & $(0.001)$ & $(0.001)$ & $(0.002)$ & $(0.003)$ & $(0.004)$ & $(0.009)$ \\
\hline \multirow[t]{2}{*}{ Financial wealth } & -0.0004 & 0.0002 & -0.0002 & 0.0045 & 0.0059 & 0.0141 \\
\hline & $(0.001)$ & $(0.001)$ & $(0.003)$ & $(0.004)$ & $(0.006)$ & $(0.012)$ \\
\hline \multirow[t]{2}{*}{ Consumer confidence } & $27.6271^{*}$ & $23.5730 * *$ & 54.2222 & $136.1536 * *$ & $191.4897 * * *$ & $389.7726 * *$ \\
\hline & $(16.530)$ & $(10.259)$ & $(34.207)$ & $(52.726)$ & $(72.888)$ & (150.481) \\
\hline $\begin{array}{l}\text { Cointegration } \\
\text { Chi-square }\end{array}$ & 65.8079 & 51.0738 & 95.5470 & 21.8989 & 26.4680 & 19.8194 \\
\hline AIC & -27.2153 & -28.5250 & -28.2159 & -30.7931 & -31.3054 & -33.1434 \\
\hline $\mathrm{BIC}$ & -26.8970 & -28.2067 & -27.8976 & -30.4747 & -30.9871 & -32.8251 \\
\hline
\end{tabular}


Table 5. Variable definition and descriptive statistics

\begin{tabular}{|c|c|c|c|c|c|c|}
\hline Variable & Definition & Obs & Mean & Std. Dev. & Min & Max \\
\hline$C$ & Energy consumption (gas and electricity) & 4293 & 1270.347 & 545.377 & 0 & 7000 \\
\hline$W$ & Housing wealth & 3979 & 242937.700 & 138936.700 & 76 & 2000000 \\
\hline$Y$ & Gross household income & 5433 & 3598.873 & 2475.861 & 0 & 20000 \\
\hline old & Whether individual is older than 60 & 5485 & 0.366 & 0.482 & 0 & 1 \\
\hline S fut & Whether subjective future financial situation is worse off & 5485 & 0.196 & 0.397 & 0 & 1 \\
\hline combined_bill & Whether energy bills are paid as a combined one or separate ones & 4824 & 0.545 & 0.498 & 0 & 1 \\
\hline conservative & Whether individuals have conservative environmental habits & 5485 & 0.541 & 0.498 & 0 & 1 \\
\hline gender & Male or not & 5485 & 0.446 & 0.497 & 0 & 1 \\
\hline ncars & Number of cars & 5420 & 1.534 & 0.959 & 0 & 6 \\
\hline hheat & Whether household is able to keep property warm enough & 5418 & 1.060 & 0.240 & 1 & 3 \\
\hline hhsize & Number of people in household & 5435 & 2.630 & 1.312 & 1 & 10 \\
\hline hsbeds & Number of bedrooms & 5428 & 3.045 & 0.963 & 0 & 7 \\
\hline owner & Whether household own property outright/with mortgage or not & 5485 & 0.799 & 0.401 & 0 & 1 \\
\hline employ & Whether individual is in paid employment & 5350 & 0.551 & 0.497 & 0 & 1 \\
\hline
\end{tabular}


Table 6. Housing wealth and energy consumption

\begin{tabular}{|c|c|c|c|c|c|}
\hline & (1) & (2) & (3) & (4) & $(5)$ \\
\hline \multirow{2}{*}{$\bar{Y}$} & $0.0030 * * *$ & $0.0021 * * *$ & $0.0021 * * *$ & $0.0021 * * *$ & $0.0021 * * *$ \\
\hline & $(0.000)$ & $(0.000)$ & $(0.000)$ & $(0.000)$ & $(0.000)$ \\
\hline \multirow[t]{2}{*}{ old } & & $-0.0166 * * *$ & $-0.0163 * * *$ & $-0.0136 * * *$ & $-0.0166^{* * *}$ \\
\hline & & $(0.003)$ & $(0.002)$ & $(0.005)$ & $(0.002)$ \\
\hline \multirow{2}{*}{ old $* \frac{W}{Y}$} & & $0.0020 * * *$ & $0.0020 * * *$ & $0.0020 * * *$ & $0.0020 * * *$ \\
\hline & & $(0.000)$ & $(0.000)$ & $(0.000)$ & $(0.000)$ \\
\hline \multirow[t]{2}{*}{ S_fut } & & $-0.0635 * * *$ & $-0.0643 * * *$ & $-0.0624 * * *$ & $-0.0635 * * *$ \\
\hline & & $(0.003)$ & $(0.011)$ & $(0.013)$ & $(0.011)$ \\
\hline \multirow{2}{*}{ S_fut $* \frac{W}{Y}$} & & $0.0087 * * *$ & $0.0087 * * *$ & $0.0085 * * *$ & $0.0087 * * *$ \\
\hline & & $(0.000)$ & $(0.001)$ & $(0.002)$ & $(0.001)$ \\
\hline \multirow[t]{2}{*}{ combined_bill } & & $-0.0055 * *$ & $-0.0043 * *$ & $-0.0060 * * *$ & $-0.0055 * * *$ \\
\hline & & $(0.002)$ & $(0.002)$ & $(0.002)$ & $(0.002)$ \\
\hline \multirow[t]{2}{*}{ combined_bill $* \frac{W}{Y}$} & & $0.0003 * * *$ & $0.0003 * * *$ & $0.0003 * * *$ & $0.0003^{* * *}$ \\
\hline & & $(0.000)$ & $(0.000)$ & $(0.000)$ & $(0.000)$ \\
\hline \multirow[t]{2}{*}{ conservative } & & $0.0062 *$ & 0.0067 & 0.0032 & 0.0062 \\
\hline & & $(0.003)$ & $(0.004)$ & $(0.006)$ & $(0.005)$ \\
\hline \multirow[t]{2}{*}{ conservative $* \frac{W}{Y}$} & & $-0.0033 * * *$ & $-0.0035 * * *$ & $-0.0024^{*}$ & $-0.0033 * * *$ \\
\hline & & $(0.000)$ & $(0.001)$ & $(0.002)$ & $(0.001)$ \\
\hline \multirow[t]{2}{*}{ gender } & & -0.0004 & -0.0005 & & -0.0004 \\
\hline & & $(0.002)$ & $(0.002)$ & & $(0.002)$ \\
\hline \multirow[t]{2}{*}{ ncars } & & $-0.0027 *$ & $-0.0030 * *$ & & $-0.0027 * *$ \\
\hline & & $(0.002)$ & $(0.001)$ & & $(0.001)$ \\
\hline \multirow[t]{2}{*}{ hheat } & & -0.0043 & -0.0015 & & -0.0043 \\
\hline & & $(0.007)$ & $(0.007)$ & & $(0.007)$ \\
\hline \multirow[t]{2}{*}{ hhsize } & & 0.0001 & 0.0003 & & 0.0001 \\
\hline & & $(0.001)$ & $(0.002)$ & & $(0.002)$ \\
\hline \multirow[t]{2}{*}{ hsbeds } & & $-0.0047 * * *$ & $-0.0048 * * *$ & & $-0.0047 * * *$ \\
\hline & & $(0.002)$ & $(0.001)$ & & $(0.001)$ \\
\hline \multirow[t]{2}{*}{ owner } & & -0.0037 & 0.0007 & & -0.0037 \\
\hline & & $(0.011)$ & $(0.004)$ & & $(0.005)$ \\
\hline \multirow[t]{2}{*}{ employ } & & $-0.0058 *$ & $-0.0058^{*}$ & & -0.0058 \\
\hline & & $(0.003)$ & $(0.004)$ & & $(0.004)$ \\
\hline \multirow[t]{2}{*}{ _cons } & $0.0158 *$ & $0.0635 * * *$ & $0.0614 * * *$ & $0.0307 * * *$ & $0.0635 * * *$ \\
\hline & $(0.009)$ & $(0.014)$ & $(0.011)$ & $(0.004)$ & $(0.010)$ \\
\hline wave dummies & yes & yes & no & yes & yes \\
\hline region dummies & yes & yes & no & yes & yes \\
\hline clustered SE & no & no & yes & yes & yes \\
\hline $\mathrm{N}$ & 3292 & 3184 & 3184 & 3292 & 3184 \\
\hline $\mathrm{R} 2$ & 0.7531 & 0.9275 & 0.9268 & 0.9200 & 0.9275 \\
\hline Adj-R2 & 0.7520 & 0.9268 & 0.9264 & 0.9194 & 0.9268 \\
\hline F-stat & $666.17 * * *$ & $1345.09 * * *$ & $2496.59 * * *$ & $1579.72 * * *$ & $2060.03 * * *$ \\
\hline
\end{tabular}

Notes: $*, * *$, and $* * *$ denote significance level of $10 \%, 5 \%$, and $1 \%$, respectively. 
Table 7. Quantile regression results: housing wealth effect on energy consumption

\begin{tabular}{|c|c|c|c|c|c|c|}
\hline & (1) & (2) & (3) & (4) & (5) & (6) \\
\hline percentile & 0.10 & 0.25 & 0.50 & 0.75 & 0.90 & OLS \\
\hline$\frac{W}{Y}$ & $0.0022 * * *$ & $0.0025^{* * *}$ & $0.0025^{* * *}$ & $0.0047 * * *$ & $0.0069^{* * *}$ & $0.0021 * * *$ \\
\hline old & $0.0018^{*}$ & $-0.0015^{*}$ & $-0.0074 * * *$ & 0.0024 & $0.0143 * * *$ & $-0.0166^{* * *}$ \\
\hline $\operatorname{old} * \frac{W}{Y}$ & $0.0001^{* * *}$ & $0.0006^{* * *}$ & $0.0016^{* * *}$ & $-0.0006^{* * *}$ & $-0.0028 * * *$ & $0.0020^{* * *}$ \\
\hline S_fut & $-0.0017^{*}$ & $-0.0023 * * *$ & $-0.0078^{* * *}$ & $-0.0114 * * *$ & $-0.0244 * * *$ & $-0.0635^{* * *}$ \\
\hline S_fut $* \frac{W}{Y}$ & $0.0004 * * *$ & $0.0006^{* * *}$ & $0.0018^{* * *}$ & $0.0026^{* * *}$ & $0.0055^{* * *}$ & $0.0087 * * *$ \\
\hline combined_bill & $-0.0028^{* * *}$ & $-0.0022 * * *$ & $-0.0038^{* * *}$ & $-0.0081 * * *$ & $-0.0110^{* * *}$ & $-0.0055^{* * *}$ \\
\hline combined_bill $* \frac{W}{Y}$ & -0.0000 & $-0.0002 * * *$ & $-0.0003^{* * *}$ & $0.0003^{* * *}$ & $0.0003^{* * *}$ & $0.0003^{* * *}$ \\
\hline conservative & $-0.0019 * *$ & $-0.0028 * * *$ & $-0.0025^{*}$ & -0.0025 & 0.0000 & 0.0062 \\
\hline conservative $* \frac{W}{Y}$ & $-0.0002 * * *$ & $-0.0003^{* * *}$ & $-0.0005^{* * *}$ & $-0.0007 * * *$ & $-0.0011 * * *$ & $-0.0033^{* * *}$ \\
\hline gender & -0.0002 & -0.0004 & -0.0004 & -0.0003 & 0.0000 & -0.0004 \\
\hline ncars & -0.0005 & -0.0006 & $-0.0012^{*}$ & $-0.0019 *$ & $-0.0022 * *$ & $-0.0027 * *$ \\
\hline hheat & $-0.0043 * *$ & -0.0015 & 0.0012 & 0.0048 & 0.006 & -0.0043 \\
\hline hhsize & $0.0017 * * *$ & $0.0010^{* * *}$ & $0.0012 * *$ & $0.0019^{* *}$ & $0.0029 * * *$ & 0.0001 \\
\hline hsbeds & $-0.0021 * * *$ & $-0.0023 * * *$ & $-0.0028^{* * *}$ & $-0.0038 * * *$ & $-0.0056^{* * *}$ & $-0.0047 * * *$ \\
\hline owner & -0.0042 & -0.0004 & -0.0007 & 0.0018 & -0.0078 & -0.0037 \\
\hline employ & $-0.0019^{* *}$ & -0.0011 & $-0.0022^{*}$ & $-0.0055^{* *}$ & $-0.0084 * * *$ & -0.0058 \\
\hline _cons & $0.0198 * * *$ & $0.0194 * * *$ & $0.0251^{* * *}$ & $0.0237 * *$ & $0.0393 * * *$ & $0.0635^{* * *}$ \\
\hline
\end{tabular}

Notes: *, **, and ${ }^{* * *}$ denote significance level of $10 \%, 5 \%$, and $1 \%$, respectively. 